\title{
A rock-carving from Westerton, Angus district
}

\section{G J Barclay* and S P Halliday $\dagger$}

In March 1978, as part of a survey of the Lunan Valley, Angus District, carried out by the Society of Antiquaries of Scotland's fieldworkers (RCAMS 1978) in conjunction with the Central Excavation Unit of the Scottish Development Department, a previously unrecorded carving was discovered on a standing stone at Westerton (NGR no 5364 5210), a cottage about $8 \mathrm{~km} \mathrm{E}$ of Forfar.

The stone is situated in an arable field immediately W of the public road, $50 \mathrm{~m}$ WNW of Westerton cottage. It measures $1 \mathrm{~m}$ by $0.25 \mathrm{~m}$ at its base and rises to a flat top at a height of $1.4 \mathrm{~m}$; on the top there are five cup-marks.

Much of the original surface of the SW face of the stone has scaled off, but, on the surviving portion, there is part of a human figure (fig 1), apparently naked, outlined by grooves measuring between $5 \mathrm{~mm}$ and $15 \mathrm{~mm}$ in breadth and up to $7 \mathrm{~mm}$ in depth. Of the head, only the lower part of the jaw and neck can be identified, and a second groove at the back of the neck probably represents hair or some form of head-covering. The left arm passes across the body into the lap and the arch of the back is shown by a groove which detaches itself from the upper part of the arm. The left leg is bent at the knee and is lost below mid-calf; from mid-calf to jaw is a distance of some $0.85 \mathrm{~m}$.

The figure is viewed from its left side and is turned slightly towards the observer. The positions of the left arm and leg may be compared with those of a fighting figure depicted on the Shandwick Stone, Easter Ross (Allen \& Anderson 1903, iii, 72) but they may also reflect a riding posture; no trace of a mount, however, has survived.

* Central Excavation Unit, Scottish Development Department (Ancient Monuments), 3-11 Melville Street, Edinburgh

† Royal Commission on Ancient and Historical Monuments of Scotland, 54 Melville Street, Edinburgh 


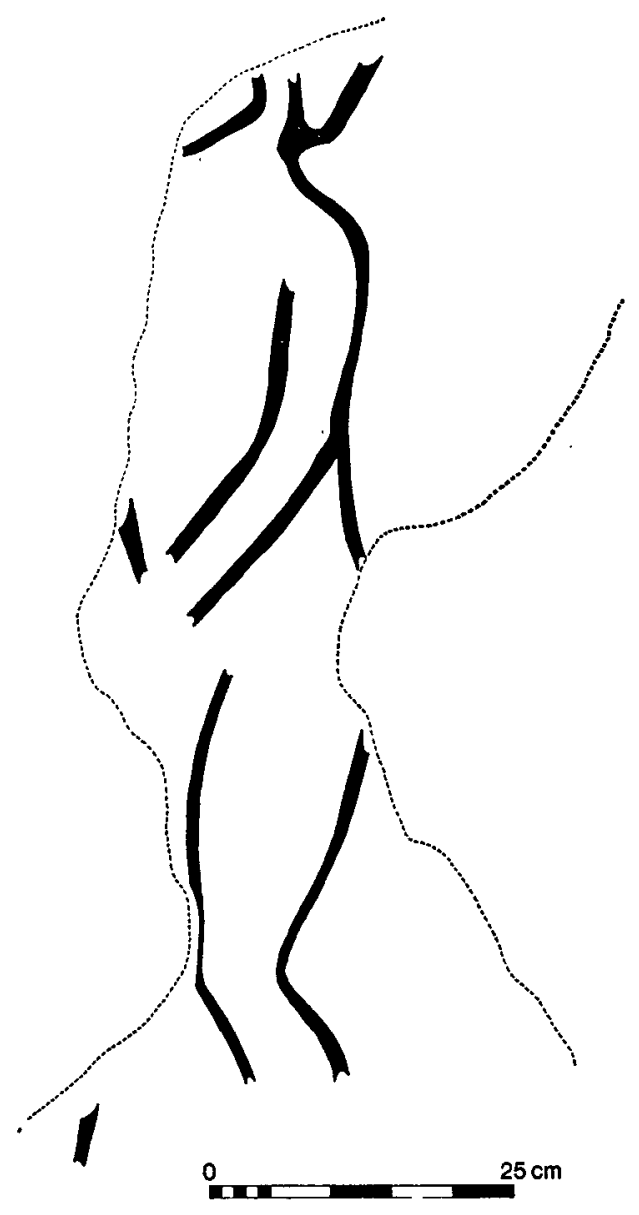

FIg 1 Rock-carving at Westerton, Angus District

In 1866, when the cup-marks were first recorded, it was claimed that the stone 'had once formed one of a fine circle of boulder stones' (Simpson 1866, 15). If so, the circle has passed unnoticed among contemporary local authors and it may even have been wishful thinking. There is no reason, however, to doubt that the stone, with its cup-marks, was erected in the second or third millennium BC. By the nature of its simplicity, the figure cannot be dated and while it may be an example of Pictish sculpture, it could equally well have been added to the stone in the more recent past.

\section{ACKNOWLEDGMENTS}

The writers would like to express their thanks to colleagues on the staffs of the Royal Commission on Ancient Monuments and the Ancient Monuments Branch of the Scottish Development Department for advice in the preparation of this note, and to Mr Michael Brooks of the Central Excavation Unit who made a photographic record of the standing stone. 


\section{REFERENCES}

Allen, J Romilly \& Anderson, J 1903 The Early Christian Monuments of Scotland. Edinburgh.

RCAMS 1978 The Archaeological Sites and Monuments of the Lunan Valley and the Montrose Basin, Angus District, Tayside Region. Society of Antiquaries of Scotland Field Survey.

Simpson, J Y 1866 'On ancient sculpturings of cups and concentric rings, etc', Proc Soc Antiq Scot, 6 (1864-6), Appendix, 1-147.

The Society is indebted to the Scottish Development Department (Ancient Monuments) for a grant towards the cost of publishing this note 